\title{
Analysis of the availability of aircrafts with alternative propulsions
}

Global air traffic doubles every 15 years. Therefore, aviation emission grows as well. It is advisable to look for an alternative aircrafts' propulsion for both commercial and general aviation (usually flying closer to the ground). There are many prototypes proposed by homemade projects, through companies wanting to extend their offer. There are also several more advanced constructions ready to self-set or serially produced. In the article the main topic are electric aircrafts as an example of possibility to reduce the toxic compounds emission. According to the analysis some of companies specializing in unmanned aircraft production, starting to expand their business with manned products. In the article, analyses of electric aircrafts different models, which are available on market and presented the comparisons characteristics based on e.g. cruise speed, range for every model or charging time were made and conclusions about alternative aircraft propulsions, were made.

Key words: aircrafts, alternative propulsions, electric aircraft

\section{Introduction}

For a long time, due to economic and ecological aspects, solutions have been sought that would minimize the use of conventional fuels in transport. Such solutions are used in various branches of transport, including road, rail and air transport [1]. The aircraft emission can cause deterioration in local air quality (near airports) and climate changes connected with gases trapping heat in the atmosphere and with formatting aerosols which lead to changes in clouds (at cruising altitude). Under the agreement of 192 members of ICAO, the global aviation emission target is $50 \%$ reduction by 2050 , however without state-of-the-art solutions it will be hard to achieve. Over the past decade, more than 70 all-electric conceptual, experimental and commercial aircrafts have been researched, with a particular focus on light aircraft [2]. Currently, in 2019 there are several models already available for production. The highest interest in electric aircrafts in Europe is in Norway. In this country, it is planned, that all short-haul flights (up to 1.5 hours) would be carried out by electric aircrafts by 2040. The first state company, to resign from aircrafts with combustion engines propulsion is Norwegian Avinor. The first flight tests of a small 19 seats passenger airplane are to begin in 2025 [3]. Furthermore, the EasyJet airline, the third world biggest low-cost carrier, announced a cooperation with American Wright Electric company in 2017. The goal of the collaboration is to create a full electric commercial airliner. Initial flights are scheduled for 2027 [4].

Nowadays, no electric commercial airliners are produced, which is way the characteristic will be based on ultralights, motor gliders and motor hang gliders. The main producer of ultralight electric aircrafts is Pipistrel. It is a Slovenian company founded in 1989 with headquarters in Ajdovscina [5]. Pipistrel is a producer of two ultralight aircraft with electric propulsion: Alpha Electro, produced since 2015 and Taurus Electro produced until 2011. The next company on the electric aircraft market is Electric Aircraft Corporation. It is an American aircraft manufacturer that produces under the brand name Electraflyer. The company is currently producing two model of aircraft with electric propulsion: the motor hang glider (Electraflyer
Trike, which has been in production since 2008 and the moto glider (ElectroFlyer ULS), which has been produced since 2012 [6]. The Alisport company also manufactures the motor gliders. It is an Italian manufacturer that deals with the creation of aircraft ready for flight and sets for amateur production. The model produced by the company is Silent 2, which is powered by solar panels [7].

\section{Characteristics of aircraft models with electric propulsions}

The first electric drive airplane to be described is Alpha Electro (Fig. 1). It is a training aircraft belonging to the group of ultralight aircraft. Alpha Electro has a wingspan of about $10.5 \mathrm{~m}$, has a two-seater, T-tail, high wing motor plane. This model is made almost entirely of composite materials. The aircraft is equipped with a solid threewheeled chassis, including wheels with breaks, a U-shaped composite rail and controllable wheel [5, 8]. Alpha Electro features flaperons, one movable surface on each wing, which simultaneously a flap and an aileron. Full dual main flight control levers make the Alpha Electro ideal for initial and advanced flight training. All aileron, elevator and flap controls are connected to the cabin controls using selffitting push-pull tubes (Fig. 2). The rudder is controlled via cables. The elevator trim is a mechanical, spring type mechanism. H-type safety belts attached to the fuselage at three mounting points are the risk minimizing features.

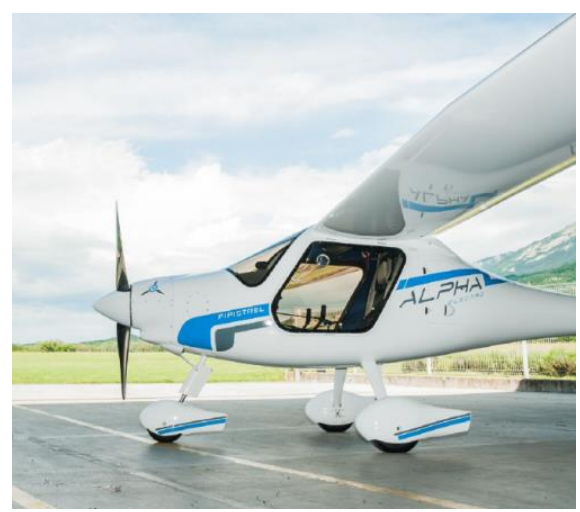

Fig. 1. Ultralight aircraft Alpha Electro [5] 
The rudder pedals can be adjusted before and also inflight to suit everybody's' dimensions and ergonomic requirements. The aircraft is equipped with two battery boxes. One is situated behind the cabin bulkhead and the second one is behind the firewall. The battery system is ventilated in order to prevent overheating. The powering unit is a $60 \mathrm{~kW}$ electric motor capable of energy recuperation during the descent. The doors, windshield and top window are made of $2 \mathrm{~mm}$ anti-UV tined Lexan, which was specially designed not to shatter or split on impact. The main wheel disk type, hydraulic brakes are activated via a cockpit hand-lever. The cabin is ventilated through the special vents fitted into the doors. The propeller is a fixed pitch three-blade design.

Due to safety reasons, the resettable electric circuit brakes enable testing individual circuit items and disconnect the batteries if needed. The full set of lights is mounted: navigational lights (NAV), anti-collision lights (AC) and a landing light (LDG).

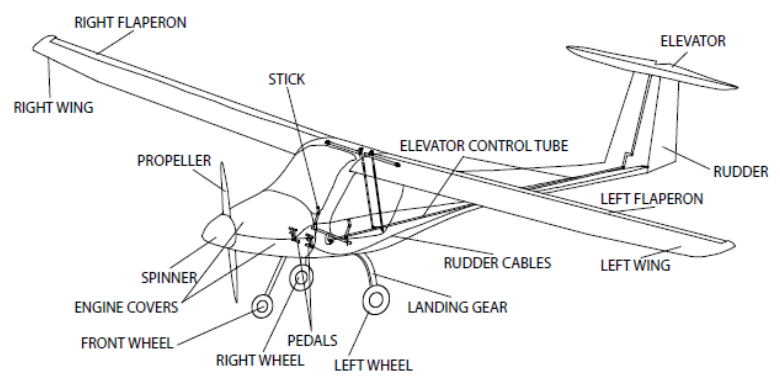

Fig. 2. Alpha Electro construction schema [7]

The next model to describe is a plane from the same manufacturer - TaurusElectro (Fig. 3). This model has got a 15-meter wingspan, T-tail and is made almost entirely of composite materials. The wing configuration is a mid-wing, the propulsion system is fully retractable in order to increase the sliding performance. The aircraft is equipped with a taildragger fully extended gear consisting of two main wheels with brakes [9]. The tail wheel is controlled by the pilot in cockpit. Like the Alpha Electro, Taurus is equipped with flappers, which are combination of flaps and ailerons, located in one deflecting surface. The flaps have 3 setting options: neutral, start and landing. All ailerons, lift and flaps are connected to the cab to be able to control using self-adjusting push-pull tubes. The lift has a mechanical trimmer placed inside the fuselage to prevent too much resistance [9].

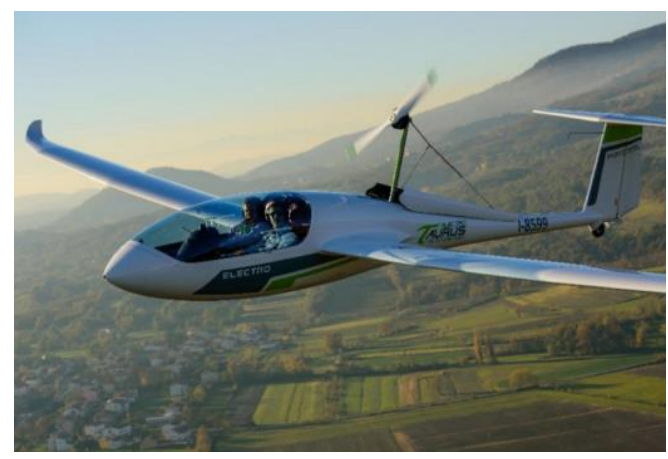

Fig. 3. Taurus Electro motor-glider [10]
All the models are equipped with H-type seat belts mounted to the fuselage in three points. The batteries are placed inside the fuselage in four metal boxes with dedicated connectors. The charging process is available only by original chargers by Pipistrel. The cabin of TaursElectro is transparent or color in blue (Fig. 4). The main brakes are hydraulic [9].

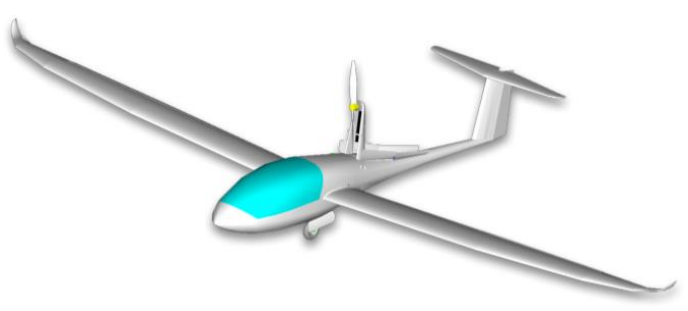

Fig. 4. Taurus Electro motor-glider model [9]

The cabin ventilation is carried out through special cables mounted on the cabin frame and can be adapted depending on the needs of the crew. To improve the aerodynamics of gliding flight, Taurus Electro has a fully automated engine start procedure. It is carried out using the switch on the dashboard. The basic instruments are installed with predetermined operational limits. The Taurus can be equipped with a ballistic parachute rescue system installed optionally (in some countries, e.g. Germany, ballistic rescue systems is required).

The next characterized model is ElectraFlyer Trike (Fig. 5). It is an ultra-light motor hang glider, equipped with an electric motor instead of a traditional gasoline engine, created by an American manufacturer - Electric Aircraft Corporation [11]. The ElectraFlyer Trike is built in accordance with the Federal Aviation Regulations, part 103. The standard ElectraFlyer is equipped with a $5.6 \mathrm{kWh}$ polymer lithium-ion battery that powers a $19 \mathrm{HP}(14 \mathrm{~kW})$ electric motor.

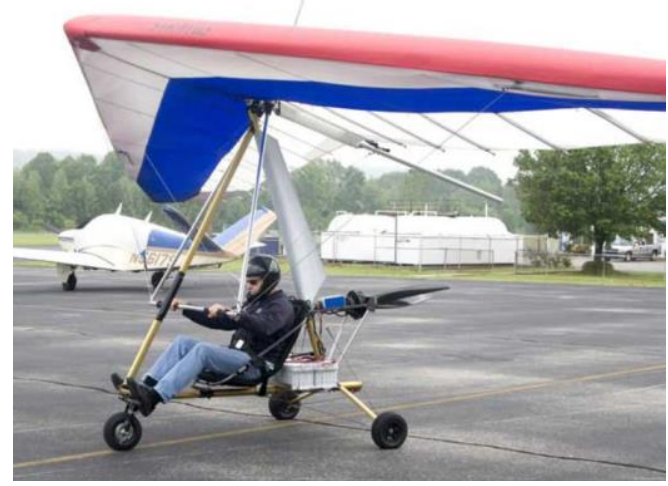

Fig. 5. Motor hang glider ElectraFlyer Trike [6]

One of the possible modernization options is changing the engine for $40 \mathrm{~km}(30 \mathrm{~kW})$ power. Charging time from standard (in USA) plug-in $(120 \mathrm{~V})$ depends on the number of batteries packs and ranges between 5 and 6 hours. Charging time can be shortcut to 2 hours with $240 \mathrm{~V}$ socket. With Stratus wing model, aircraft gross weight can be reduced to $113 \mathrm{~kg}$. There is a possibility of installing an emergency parachute. 
The next electric aircraft to be described is ElectraFlyer - ULS (Fig. 6), manufactured by the same company. Electra Flyer - ULS is projected in accordance with FAR rules, part 103 (Ultralight Vehicles) [12]. In pursuance of the empty weight limitation - category $115 \mathrm{~kg}$ - of these rules, the motor-glider's empty weight is $111 \mathrm{~kg}$. It's a mid-wing construction, one-seater, stall three wheeled gear and single electric engine [12].

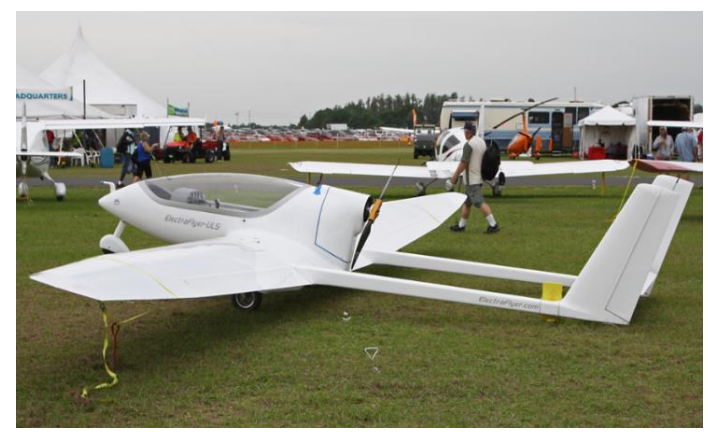

Fig. 6. Electra Flyer - ULS [13]

The glider is made of composite materials - carbon fiber and foam. The engine and the propulsion system are supplied by electric aircraft corporation, while the airframe is built in cooperation with Airsport in Czech Republic and is adapted from the existing project - Airsport Song. The propulsion system includes a Fishman $20 \mathrm{HP}(15 \mathrm{~kW})$ engine, an electronic controller and a $3.3 \mathrm{kWh}$ Li-Po battery pack [12]. Optionally, the model can be equipped with an additional battery with a capacity of $3.3 \mathrm{kWh}$, which gives two hours of durability. A two-blade propeller with a fixed pitch is standard equipment. Additionally, the motor glider can be equipped with a folding propeller made of carbon fiber.

The next described aircraft is Silent 2 Electro. It is a single-seat, self-launching microlight sailplane. The aircraft is made of carbon fiber and glass-fiber, has a wingspan of $13.5 \mathrm{~m}$ (Fig. 7) and "T" tail configuration [7].

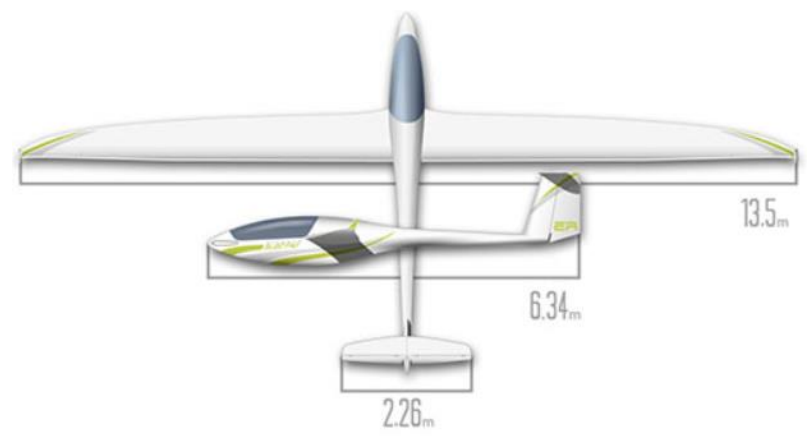

Fig. 7. Motor-glider Alisport Silent 2 dimensions [7]

The control system consists of a speed brake, a flaperons, rudder, variable incidence tail plane and elevator are operated by a system of pulleys, cables and pushers. The glider's tail is connected, via a cable, to the flap control. The pilot's seat, which is not adjustable, is covered with a two-piece pillow connected by a zip fastener, which is attached to the seat base and at the back by Velcro fasteners. The glider is equipped with adjustable rudder pedals.

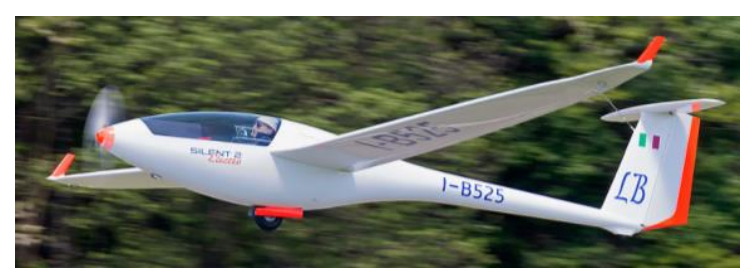

Fig. 8. Alisport Silent 2 [13]

The canopy is attached to the glider by a hinge at the front edge of the canopy frame (Fig. 8). It is locked by means of two locking pins on each side of the rear part of the frame. The left locking pin supports a microswitch mounted on the inside of the fuselage that provides the "canopy closed" signal to the controller. The front Electric Self-launch system consists of two lithium-polymer batteries, a controller, a control unit, a $22 \mathrm{~kW}$ brushless motor and two fixed pitch propellers. The electric motor is located in the nose of the aircraft and when it does not work, the propeller blades, are folded back. Two lithium-polymer batteries are connected in series and are placed in a compartment behind the cockpit. When fully charged, the batteries have a total capacity of $4.3 \mathrm{kWh}$. Propeller rotations are set using the throttle/brake. The distance necessary to take off on the asphalt is $140 \mathrm{~m}$, and the engine provides a climb speed of $2.0 \mathrm{~m} / \mathrm{s}(400 \mathrm{ft} / \mathrm{min})$ [7]

The last discussed model of an electrically powered airplane is MC E15 Cri-Cri (Fig. 9). It was designed by a French engineer Michel Colomban. The production, the model deals with the European Aeronautic Defense and Space Company. It is the smallest single-seat ultralight aircraft.

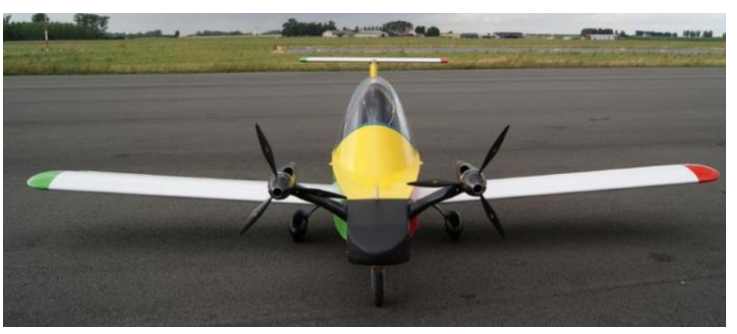

Fig. 9. MC-15 Cri-Cri airplane [14]

It is made of metal construction and light composite materials. It has a T-tail. The Cri-Cri was the world's first electric-powered aircraft.

The aircraft's propulsion consists of four brushless 2JPX PUL 212 electric motors, each with 15 HP. The energy is provided by lithium batteries with a capacity of around $4 \mathrm{~kW}$.

Wingspan of this model is $4.90 \mathrm{~m}$, length $3.90 \mathrm{~m}$ and height $3.10 \mathrm{~m}$ (Fig. 10). The weight of the aircraft is $80 \mathrm{~kg}$, and the maximum weight is $170 \mathrm{~kg}$. Cri-Cri can climb at a maximum speed of $3 \mathrm{~m} / \mathrm{s}$ and develop speeds up to 220 $\mathrm{km} / \mathrm{h}$ [16]. The aircraft can perform a flight for about 30 minutes.

Apart from described models, there are also other manufacturers constructing electric aircrafts e. g.: Solar Impulse, Magnus or Rutan [17]. However, these are prototypes, university projects, aircrafts on the development stage, or special purpose constructions, thus they are not a part of this comparison. 


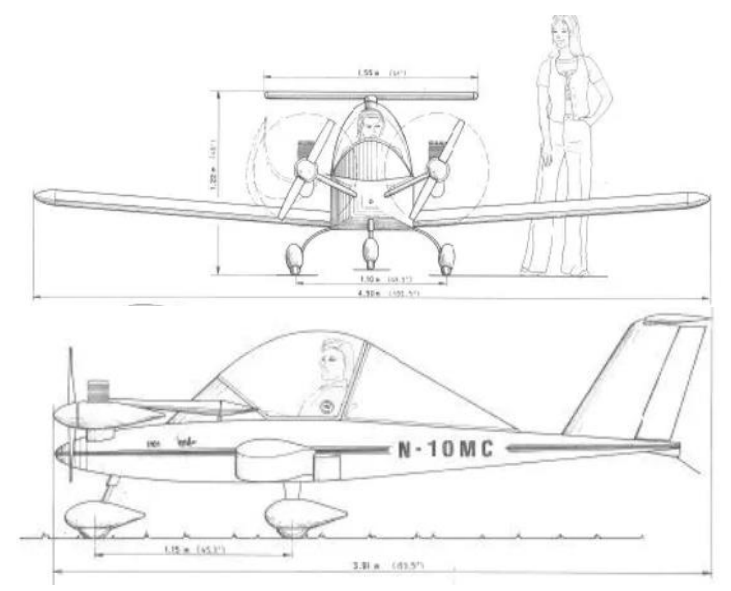

Fig. 10. MC-15 Cri-Cri airplane dimensions [15]

\section{Comparison of the solutions available on the electric aircrafts' market}

In order to perform the analysis of available electric aircrafts solutions, the assessment criteria were chosen. The criteria available for almost every aircraft are: number of engines, engines power, batteries capacity, cruise speed, flight time, Maximum Take Off Weight (MTOW) and charging time for two different voltage chargers (Table 1).

Table 1. Comparison of aircrafts models according to parameters available

\begin{tabular}{|l|c|c|c|c|c|}
\hline Aircraft model & Aircraft type & $\begin{array}{c}\text { Engine } \\
\text { count }\end{array}$ & $\begin{array}{c}\text { Engines } \\
\text { power } \\
{[\mathrm{kW}]}\end{array}$ & $\begin{array}{c}\text { Batteries } \\
\text { capacity } \\
{[\mathrm{kWh}]}\end{array}$ & $\begin{array}{c}\text { Cruise } \\
\text { speed } \\
{[\mathrm{km} / \mathrm{h}]}\end{array}$ \\
\hline Electraflyer Trike & hang glider & 1 & 13.5 & 5.6 & 48.4 \\
\hline Electraflyer ULS & $\begin{array}{c}\text { ultralight } \\
\text { motor glider }\end{array}$ & 2 & 27 & 6.6 & 64.4 \\
\hline $\begin{array}{l}\text { Pipistrel Alpha } \\
\text { Electro }\end{array}$ & airplane & 2 & 50 & 42 & 157 \\
\hline $\begin{array}{l}\text { Pipistrel Taurus } \\
\text { Electro G2 }\end{array}$ & motor glider & 4 & 54 & 22.8 & 163 \\
\hline Silent 2 Electro & motor glider & 1 & 13.5 & 4.4 & 70 \\
\hline $\begin{array}{l}\text { MC15E } \\
\text { Cri-Cri }\end{array}$ & airplane & 2 & 27 & 4 & 110 \\
\hline
\end{tabular}

\begin{tabular}{|c|c|c|c|c|c|}
\hline Aircraft model & Aircraft type & $\begin{array}{c}\text { Flight } \\
\text { time }[\mathrm{h}]\end{array}$ & $\begin{array}{c}\text { MTOW } \\
{[\mathrm{kg}]}\end{array}$ & $\begin{array}{c}\text { Charging } \\
\text { time }-110 \mathrm{~V} \\
\text { charger }[\mathrm{h}]\end{array}$ & $\begin{array}{c}\text { Charging } \\
\text { time }-220 \mathrm{~V} \\
\text { charger }[\mathrm{h}]\end{array}$ \\
\hline Electraflyer Trike & hang glider & 1.5 & 112 & 6 & 2 \\
\hline Electraflyer ULS & $\begin{array}{c}\text { ultralight } \\
\text { motor glider }\end{array}$ & 2 & 238.14 & 4 & 1 \\
\hline $\begin{array}{c}\text { Pipistrel Alpha } \\
\text { Electro }\end{array}$ & airplane & 1.25 & 550 & 8 & 1.6 \\
\hline $\begin{array}{c}\text { Pipistrel Taurus } \\
\text { Electro G2 }\end{array}$ & motor glider & 2 & 450 & 5.5 & 3.5 \\
\hline Silent 2 Electro & motor glider & 1 & 300 & - & - \\
\hline MC15E Cri - Cri & airplane & 0.42 & 170 & - & - \\
\hline
\end{tabular}

In case of two models: Silent 2 Electro and MC15 CriCri, it was not possible to find information on the charging time. All the models discussed are in production, but very often (e.g. Electraflyer Trike and ULS) are manufactured directly for the customer, according to his order. Thus, there are very few of them in use. Electraflyer models are often delivered in separate parts, so that the customer could connect them himself, which means these are models for people interested in broadly understood avionics and aircraft construction.

Next, in order to make an analysis, the characteristics based on the data contained in table 1 will be discussed.
Figure 11 shows the take-off mass for individual aircraft model. The take-off mass is stated in kilograms, varies from $112 \mathrm{~kg}$ to $550 \mathrm{~kg}$ and depends mainly on the size of the model and its construction.

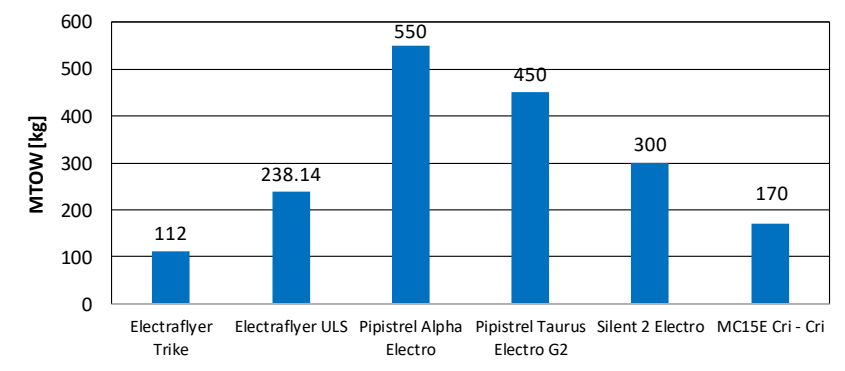

Fig. 11. The Maximum Take Off Weight bar chart

The Pipistrel Alpha Electro has the largest MTOW from all the aircrafts mentioned (Fig. 11). It's $550 \mathrm{~kg}$. Its take-off mass is justified by its size - it is the largest of the models discussed and belongs to ultralights which distinguishes it from other moto-hang gliders or motor gliders. The second model with a big take-off weight is the motor glider, by the same manufacturer - Taurus Elelctro G2. It has a take-off weight of $450 \mathrm{~kg}$. Silent 2 Electro, also a glider, created by the Alisport manufacturer, is the next aircraft with a slightly lower take-off weight. It is slightly smaller than the Pipistrel motor glider - the difference in the wingspan is about 1.5 meters. The next motif is Electraflyer ULS, whose MTOW is $283 \mathrm{~kg}$, while the weight of an empty aircraft is $111 \mathrm{~kg}$. The MC-15E Cri-Cri model has a take-off weight of $170 \mathrm{~kg}$. The plane itself weighs $80 \mathrm{~kg}$, and is the smallest of the aircraft in question with a wingspan of about 5 meters. The lightest among the discussed ones, is the ultralight Electrafyler Trike. The take-off weight of the hang glider is less than $113 \mathrm{~kg}$.

The following is a description of the engine performance, number of engines and the speed of the aircraft models in question (Fig. 12). The power shown refers to the sum of the power generated by all the engine, i.e. if the Electraflyer ULS generates $27 \mathrm{~kW}$ and has two motors, then each motor produces $13.5 \mathrm{~kW}$.

The Pipistrel Taurus Electro G2 has got the biggest power coming from 4 engines, which all together gives $54 \mathrm{~kW}$ power (Fig. 12). Furthermore, the ultra light plane Alpha Electro produces about $50 \mathrm{~kW}$ of power, using 2 engines, or about $25 \mathrm{~kW}$ each. The Electraflyer ULS motor glider and the MC15E Cri-Cri ultra-light aircraft generate about $27 \mathrm{~kW}$ of power using two powering units. The Motorminer Silent 2 Electro and the Electraflyer Trike are equipped with one electric motor that provides $13.5 \mathrm{~kW}$ of power. As can be seen, most of the aircraft models in question have $13.5 \mathrm{~kW}$ motors, only in different quantities. Only in the case of the ultra-light Alpha Electro aircraft, two $25 \mathrm{~kW}$ drive units were used. It is known that, the speed of any means of transport with an electric or combustion engine depends mainly on the engine power. An important parameter in terms of the speed achieved is also the takeoff weight of a given type of aircraft. The aircraft with the highest cruising speed is moto glider Taurus Electro G2, whose performance is $163 \mathrm{~km} / \mathrm{h}$. 


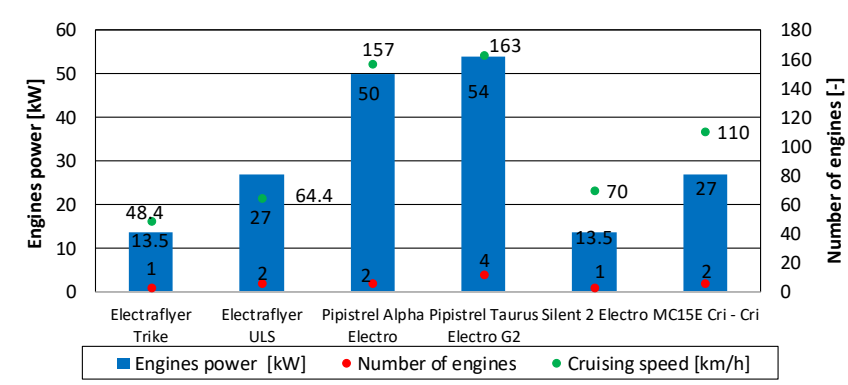

Fig. 12. The number of engines and their power

The ultra-light Alpha Electro model and the MC15E Cri-Cri are also characterized by a great value of cruising speed compared to other models. These aircraft reach $157 \mathrm{~km} / \mathrm{h}$ and $110 \mathrm{~km} / \mathrm{h}$ respectively. The aircraft with the lowest cruise speed is Electraflyer Trike. However, the type of this aircraft should be taken into account. It is a motor hang-glider, so achieving high cruising speeds is not a priority. Two aircraft models: the MC15E Cri-Cri and the Electraflyer ULS have the same engine power, but achieve different maximum cruising speeds. It is caused by the mass of these two models. The Electraflyer motor glider is $70 \mathrm{~kg}$ heavier than the ultra-light MC15E Cri-Cri.

Figure 13 presents the dependence covering three series of data: battery capacity for the discussed aircraft models, flight time and power of installed engines. The flight time depends primarily on the battery capacity and the power generated by the electric motors. If the capacity of the batteries is too small in relation to the power that the engines produce, the flight range will not be long. This is the case for the MC15E Cri-Cri model, which is able to stay in the air for only about 30 minutes, because the capacity of its batteries does not last long enough to generate installation power in the aircraft's propulsion units.

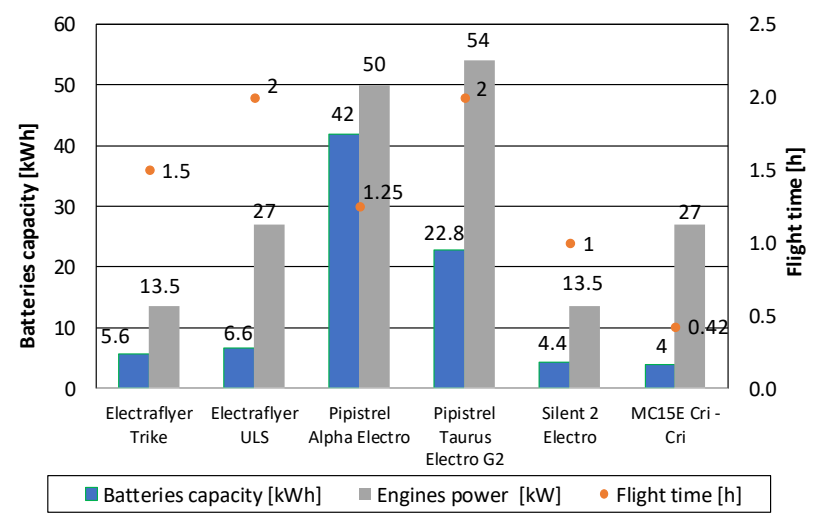

Fig. 13. The flight time, batteries capacity and engines power chart

The longest flight time is 2 hours and is possible to achieve flying Pipistrel TaurusElectro G2 and Electraflyer ULS as well (Fig. 13). Both models differ significantly in the capacity of batteries and engine power - Taurus Electro has about 3.5 times more battery capacity and twice as much engine power. As it can be noticed, the Electraflyer ULS can stay in the air as long as the Taurus Electro G2, despite the much smaller capacity of the batteries. This is due to the power of engines, Electraflyer ULS will have much lower performance associated with, for example, cruising speed compared to the Taurus Electro G2. Aircraft that also provides a long flight time is the Electraflyer Trike. When charging to $100 \%$, air operations can be performed for about 1.5 hours.

Figure 14 shows the cost of charging these aircrafts. The prices were calculated only for four of the six models discussed, because there are no information on charging models MCE15 Cri-Cri and Silent Electro 2. The Pipistrel company has its own charging station dedicated for two discussed aircraft models - ultralight Alpha Electro and a Taurus Electro G2 motor glider. The price for charging in a dedicated station is $2 €$ for $1 \mathrm{kWh}$. Referring the price to the battery capacity, the results presented in the chart were obtained. The charging costs for Electraflyer Trike and Electraflyer ULS were calculated using data from the manufacturer - price $0.53 €$ per $1 \mathrm{kWh}$. The largest costs of using are in case of Alpha Electro. This is due to the large capacity of the battery, which is enough to charge 2 electric motors that keep the plane in the air. The lowest cost of charging is characteristic for the Electraflyer aircraft models. Both models are equipped with low-capacity batteries and the charging rate is very small compared to the price of the Pipistrel charging station. In addition, the charging costs of the models in question were converted into Polish zlotys (PLN). The calculations were made in accordance with the Euro rate as at $14 / 02 / 2019$. The calculations related to the exchange rate were made to better present the costs for possible Polish users and, to summarize the work, be able to compare the prices of aircraft usage with those applicable to car vehicle users.

The operating costs are significantly different from those connected with piston engines aircrafts usage. For example, the basic airplane Private Pilot License (PPL(A)) training lasts at least 200 hours. A very popular training airplane (Cessna $172 \mathrm{P}$ ) consumes about. 401 of fuel. The price for 1 liter of AvGas is about 8.12 PLN it gives 64,960 PLN for fuel per training PPL pilot. If the pilot would be trained at Alpha Electro the price for training would be 58,195 PLN. What gives more than 6,500 PLN of savings. It can be stated that flying an electric aircraft is not only advisable for ecological reasons, but also economical ones, which is usually more appealing argument.

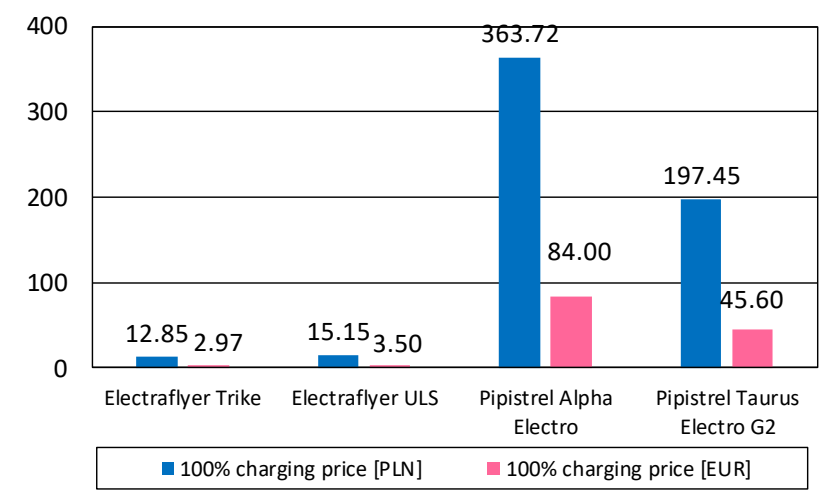

Fig. 14. Full charge costs

\section{Conclusions}

Electric aircrafts can deliver an opportunity for highspeed journeys between city centers in the future [18]. 
In the article, the analysis of available aircrafts with electric propulsions were made. It can be stated, that in the last few years there has been a significant development of work carried out in this field. Currently, several models of fully electric aircraft are available. These are mainly ultralight aircraft and powered gliders. There are many works related to the production of electric aircraft, but none of the prototypes is officially produced. These models are now used not only for recreational aviation but also for training. Some of the manufacturers also have special charging stations for ultralight aircraft. In addition, the prices charged for one full charge of an ultralight aircraft are comparable to the costs of charging a car with an electric SUV with a high capacity of batteries. Which means, they can sooner, or later replace cars on interurban travels. The only disad- vantage of aircraft with electric drive is a limited flight time, which in case of using batteries and electric motors is very short and allows to perform air operations in the air for a maximum of 2 hours.

The biggest advantage of all the models of transport modes discussed is the zero or significantly reduced carbon dioxide emission and the very low level of noise emitted. Nowadays, actions for sustainable development are a very important aspect. The society should be aware of the importance of reducing pollutants emitted to the atmosphere by human beings and through actions related to the design and development of transport means with alternative propulsion sources give an example and inspiration to care for the common environment without negatively affecting the development of future generations.

\section{Nomenclature}

AC Anti-Collision lights

ICAO International Civil Aviation Organization

LND Landing light

EU European Union

FAR Federal Aviation Regulation

GPS Global Positioning System

HP Horse Power
MTOW Maximum Take Off Weight

NAV Navigational lights

PPL(A) Private Pilot Licence (Airplane)

ULS Ultra Light Series

USA United States of America

UV Ultra-Violet

\section{Bibliography}

[1] PIELECHA, I., CIEŚLIK, W., FLUDER, K. Analysis of energy management strategies for hybrid electric vehicles in urban driving conditions. Combustion Engines. 2018, 173(2), 14-18.

[2] SCHÄFER, A.W. et al. Technological, economic and environmental prospects of all-electric aircraft. Nat. Energy. 2019, 4(2), 160-166.

[3] WINNICKI, P. Już nie tylko samochody. Norwegia chce, aby samoloty były na prąd. 2018. [Online]. Available: http://wyborcza.pl/7,155287,22913891,juz-nie-tylkosamochody-norwegia-chce-aby-samoloty-bylyna.html?disableRedirects=true. [Accessed: 01-Apr-2019].

[4] MOLL, J. EasyJet wprowadzi elektryczne samoloty pasażerskie w ciągu 10 lat | tylkonauka.pl. 2017. [Online]. Available: https://tylkonauka.pl/wiadomosc/easyjet-wprowadzi-

elektryczne-samoloty-pasazerskie-w-ciagu-10-lat. [Accessed: 01-Apr-2019].

[5] Alpha Electro-Pipistrel. [Online]. Available: https:// www.pipistrel-aircraft.com/aircraft/electric-flight/alphaelectro. [Accessed: 01-Apr-2019].

[6] www.electraflyer.com/trike.php

[7] Home - AlisportAlisport. [Online]. Available: http://www. alisport. com. [Accessed: 01-Apr-2019].

Prof. Paweł Fuć, DSc., DEng. - Faculty of Transport Engineering, Poznan University of Technology.

e-mail:pawel.fuc@put.poznan.pl
[8] Pipistrel, Pilot's Operating Handbook (POH). A00. 2017.

[9] Pipistrel, Taurus Electro Flight manual and Maintenance manual. 2008, 2.

[10] Inside EVs | Electric Vehicle News, Reviews, and Reports. [Online]. Available: https://insideevs.com. [Accessed: 01Apr-2019].

[11] BAYERL, R., BERKEMEIER, M. World directory of leisure aviation. World directory of leisure aviation-catalogue: english edition: 1000 paragliders, ultralights, microlights, para-motors, hang gliders, homebuilts, gyros, helicopters, accessories, including full, Editions Rétine. 2011, 210.

[12] TACKE, W., MARIANO, B., AL, E. World Directory of Light Aviation. 2015.

[13] flickr.com

[14] cricri.zoomshare.com

[15] newatlas.com

[16] samoloty.pl

[17] International Civil Aviation Organization (ICAO). Doc. 8643 - Aircraft Type Designators. 2019.

[18] ŚWIĄTEK, P., FUĆ, P. Analysis of combustion engine design differences between vehicle and ultralight aircraft engines. Combustion Engines. 2015, 162(3), 703-707.

\footnotetext{
Marta Maciejewska, MEng. - Faculty of Transport Engineering, Poznan University of Technology.

mail:marta.r.maciejewska@doctorate.put.poznan.pl
}

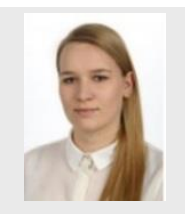

Monika Kardach, MEng. - Faculty of Transport

Engineering, Poznan University of Technology.

e-mail:

monika.t.kardach@doctorate.put.poznan.pl 